Whitman, The Galaxy, and Democratic Vistas," American Literature, 23 (1951), 341-348; Harold W. Blodgett, "Demoratic Vistas-100 Years Later," in Geschichte und Gesellschaft in der americaner Literatur, ed. Karl Schubert and Ursula Müller-Richter (Heidelberg: Quelle \& Meyer, 1975), pp. 114-131; Scott Giantvalley, Walt Whitman, 1838-1939: A Reference Guide (Boston: G. K. Hall, 1981), pp. 24-26, 27, 30, 34, 76. Mencken's comment appears in "The National Letters," in The Vintage Mencken, ed. Alistair Cooke (New York: Vintage, 1958), p. 86.

3 Letters of William Michael Rossetti Concerning Whitman, Blake, and Shelley to Anne Gilchrist and her Son Herbert Gilchrist, ed. Clarence Gohdes and Paull Franklin (1934; rpt., New York: AMS Press, 1968), p. 63.

4 The reviewer seems to have taken quotations as he read $D V$ from beginning to end. The quoted passages in the review, in the same order that they are quoted from $D V$, may be found in the New York University Press edition on pages 362, 363, 363, 363, 365, 370, 372, 374, $374,374-375,378,380,415,418-419,421-422$.

\title{
WHITMAN AND VAN GOGH: STARRY NIGHTS AND OTHER SIMILARITIES
}

Van Gogh's admiration for Whitman has been noted by scholars of both the American poet and the Dutch painter. ${ }^{1}$ He expressed his admiration in a letter to his sister written in the Fall of 1888:

Have you read the American poems by Whitman? I am sure Theo [their brother] has them, and I strongly advise you to read them, because to begin with they are really fine, and the English speak of them a good deal. He sees in the future, and even in the present, a world of healthy, carnal love, strong and frank - of friendship - of work - under the great starlit vault of heaven a something which after all one can only call God-and eternity in its place above this world. At first it makes you smile, it is all so candid and pure; but it sets you thinking for the same reason. ${ }^{2}$

There are a number of interesting similarities between the poet and the painter. Rather similar personality types, both approached life with remarkable intensity which Mark Van Doren has termed, in Whitman's case, "erethistic," i.e., ". . . persons whose organs and tissues are chronically in a state of abnormal excitement, who tremble and quiver when the rest of us are merely conscious that we are being interested or pleased." 3 They each responded powerfully to other human beings; their comradeship could have been neither easy nor comfortable because of their intensity. The issue of their sexuality is still interesting to psychologists long after the artists' deaths - the Freudian tendency is to identify van Gogh as a latent homosexual. Neither was terribly concerned with the trappings of proper dress or behavior. Whitman's lusty democratic stance is paralleled by van Gogh's belief in the essential dignity and worth of the common man so evident in his paintings of work-worn peasants. In the realm of art, they admired and were inspired by some of the same writers-most notably, Emerson, Dickens and Carlyle. While neither was religious in an orthodox or sectarian sense, both knew the Bible intimately and it is echoed throughout their work. Both were acquainted with and emulated Eastern art and philosophy. Finally, they saw themselves as intermediaries between the outmoded art of the past and the shining new art of the future. 


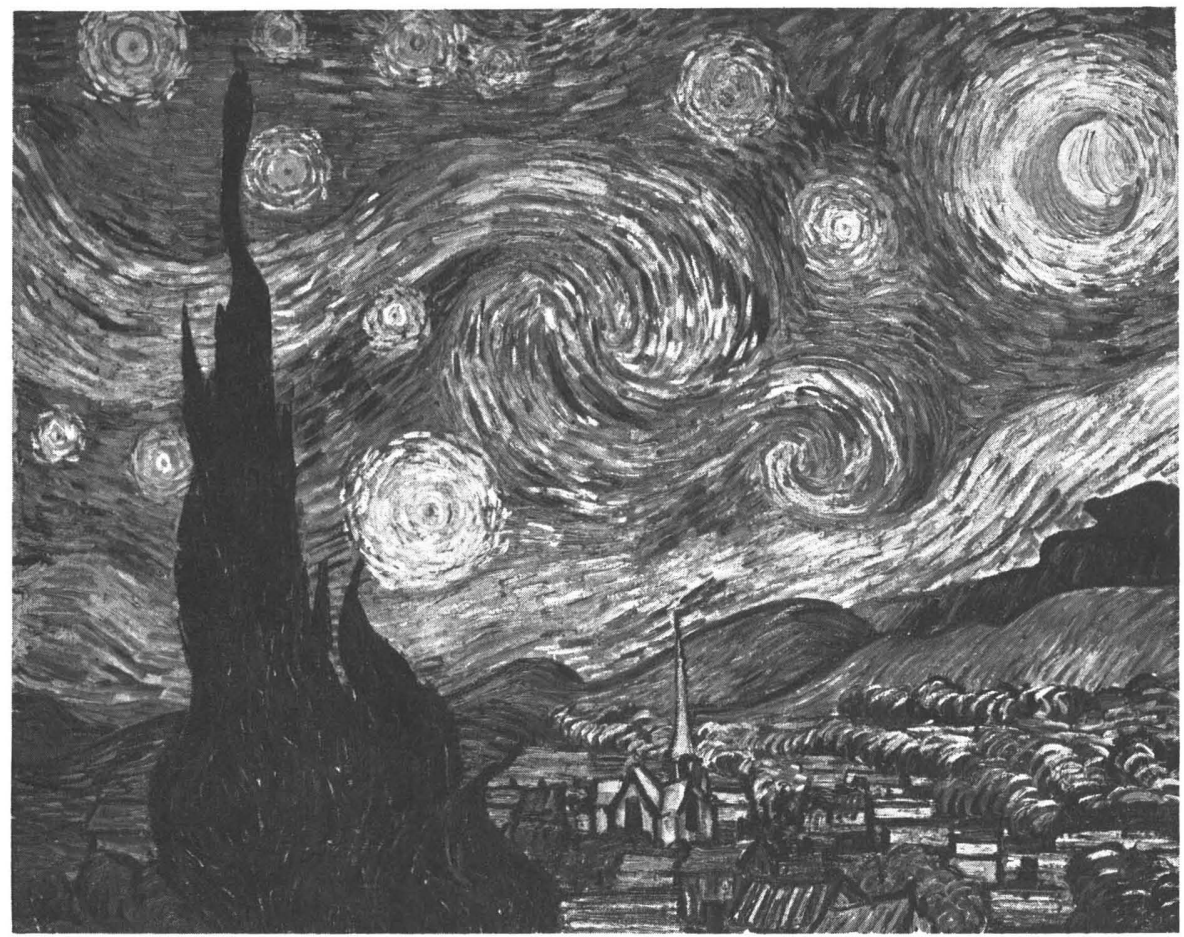

Figure 1. Vincent van Gogh. The Starry Night (1889), oil on canvas, 29 x 361/4". Collection, The Museum of Modern Art, New York, acquired through the Lillie P. Bliss Bequest.

Beyond these resemblances, there is a deeper similarity between the beliefs of these two men who never met. They both passionately loved nature and celebrated its myriad and complex beauties with unparalleled expressiveness. And in keeping with a deepseated Romanticism, both found evidence in the world around them of the divine. The astonishing scope of Whitman's mind and imagination has often been called mythical or cosmic. I believe that it is appropriate to apply these words as well to van Gogh's most inspired visions of nature and man's place in it.

This "cosmic consciousness" is most evident in their poetic and painted visions of the night sky. ${ }^{4}$ Not long after van Gogh wrote of his admiration for Whitman to his sister, he underwent a mental crisis. Fearing for his sanity, he voluntarily committed himself to the insane asylum of St. Paul's at St. Remy. There he painted one of his most famous works, his masterpiece entitled Starry Night (Fig. 1). The painting depicts a sleeping village dwarfed by a cosmic spectacle of spiraling clouds, haloed stars, and a glowing orb embraced by a crescent moon. The predominant electric blues and violets flow in swirling, watery rhythms across the sky and land. A dark, flamelike tree -in van Gogh's words a "funereal cypress" (\#541, 596)-bridges the gap between earth and sky. The stars wheel across the sky, each pin-prick of light increased to great magnitude by a spreading yellow-orange nimbus. Their arrangement is harmonious, but no particular constellation is depicted. 
Van Gogh early associated the stars with eternal divine love as, for instance, in a letter to his brother Theo of July 1877:

The moon is still shining, and the sun and the evening star, which is a good thing-and they also speak of the Love of God, and make one think of the words: Lo, I am with you alway, even unto the end of the world. $(\# 101 a)^{5}$

In Starry Night, van Gogh created an image of divine love and of the glory and immensity of the cosmos. In the painting, man's temporal and terrestrial existence is contrasted with the immutable and eternal nature of cosmic time. ${ }^{6}$ Van Gogh found hope and comfort in the stars; the immutable cycling of the stars in their courses and the phases of the moon intimated immortality. In June 1888 , he wrote to his artist friend Emile Bernard:

... seeing that nothing opposes it-supposing that there are also lines and forms as well as colors on the other innumerable planets and suns - it would remain praiseworthy of us to maintain a certain serenity with regard to the possibilities of painting under superior and changed conditions of existence, an existence changed by a phenomenon no queerer and no more surprising than the transformation of the caterpillar into a butterfly. ...

The existence of painter-butterfly would have for its field of action one of the innumerable heavenly bodies, which would perhaps be no more inaccessible to us, after death, than the black dots which symbolize towns and villages on geographical maps are in our terrestrial existence.

Science-scientific reasoning-seems to me an instrument that will lag far, far behind. For look here: the earth has been thought to be flat. It was true, so it still is today, for instance between Paris and Asnieres. Which, however, doesn't prevent science from proving that the earth is principally round. Which no one contradicts nowadays.

But notwithstanding this they persist nowadays in believing that life is flat and runs from birth to death. However, life too is probably round, and very superior in expanse and capacity to the hemisphere we know at present. (\#B8)

He expanded on the idea of a transformed, celestial existence in a letter to his brother written a short time later:

Is the whole of life visible to us, or isn't it rather that this side of death we see only one hemisphere?

Painters - to take them alone-dead and buried speak to the next generation or to several succeeding generations through their work.

Is that all, or is there more to come? Perhaps death is not the hardest thing in a painter's life.

For my own part, I declare I know nothing whatever about it, but looking at the stars always makes me dream, as simply as I dream over the black dots representing towns and villages on a map. Why, I ask myself, shouldn't the shining dots of the sky be as accessible as the black dots on the map of France? Just as we take the train to Tarascon or Rouen, we take death to reach a star. One thing undoubtedly true in this reasoning is that we cannot get to a star while we are alive, any more than we can take the train when we are dead.

So to me it seems possible that cholera, gravel, tuberculosis and cancer are the celestial means of locomotion, just as steamboats, buses and railways are the terrestrial means. To die quietly of old age would be to go there on foot. (\#506) 
There are a number of literary parallels to van Gogh's use of stars in his letters and in his paintings. The closest parallel, however, can be found in Walt Whitman's poetry. ${ }^{7}$ As Stephen Tanner has shown, Whitman was preoccupied with the night sky. ${ }^{8}$ Tanner writes that "... Whitman viewed the star-filled heavens as a symbol of an eternal realm which impinges at all times upon the changing flux of the everyday world." $\mathrm{He}$ cites several "emotional aspects" present in Whitman's star passages, such as the contrast they offer between the temporary human realm (e.g., the horrors of the Civil War) and the enduring cosmic realm. The stars refreshed, comforted and inspired Whitman. More important, though, are their spiritual implications. Whitman saw in them the glory of God, and, in contemplating them, he sensed answers to profound questions of life and death. Tanner includes Whitman's meditation on Carlyle from Specimen Days of 1881:

... Carlyle, and his approaching-perhaps even the actual-death, filled me with thoughts eluding statement, and curiously blending with the scene. The planet Venus, an hour high in the west, with all her volume and lustre recover'd [a description of the constellations visible follows].... While through the whole of this silent indescribable show, inclosing and bathing my whole receptivity, ran the thought of Carlyle dying. (To soothe and spiritualize, and, as far as may be, solve the mysteries of death and genius, consider them under the stars at midnight).

And now that he has gone hence, can it be that Thomas Carlyle, soon to chemically dissolve in ashes and by winds, remains an identity still? In ways perhaps eluding all the statements, lore and speculations of ten thousand years-eluding all possible statements to mortal sense-does he yet exist, a definite, vital being, a spirit, an individual-perhaps now wafted in space among those stellar systems, which, suggestive and limitless as they are, merely edge more limitless, far more suggestive systems. I have no doubt of it. In silence, of a fine night, such questions are answer'd to the soul, the best answers that can be given. With me, too, when depress'd by some specially sad event, or tearing problem, I wait till I go out under the stars for the last voiceless satisfaction. ${ }^{10}$

Like van Gogh, Whitman linked the stars, death and immortality. The most famous instance of this occurs in "When Lilacs Last in the Dooryard Bloom'd":

Come lovely and soothing death, Undulate round the world, serenely arriving, arriving, In the day, in the night, to all, to each, Sooner or later delicate death.

Prais'd be the fathomless universe,

For life and joy, and for objects and knowledge curious, And for love, sweet love-but praise! praise! praise!

For the sure-enwinding arms of cool-enfolding death.

The night in silence under many a star,

The ocean shore and the husky whispering wave whose voice I know, And the soul turning to thee $O$ vast and well-veil'd death, And the body gratefully nestling close to thee. ${ }^{11}$

The sibilant linking of stars and water with soothing, welcoming death has visual parallels in the flowing sky and landscape of van Gogh's painting. Both poem and 
painting record threshold experiences of immortality and infinity rendered visible and audible through finite detail.

Death, stars and water imagery are also linked in "On the Beach at Night Alone":

On the beach at night alone,

As the old mother sways her to and fro singing her husky song,

As I watch the bright stars shining, I think a thought

of the clef of the universes and of the future.

A vast similitude interlocks all,

All spheres, grown, ungrown, small, large, suns, moons, planets,

All distances of place however wide,

All distances of time, all inanimate forms,

All souls, all living bodies though they be ever so different, or in different worlds,

All gaseous, watery, vegetable, mineral processes, the fishes, the brutes,

All nations, colors, barbarisms, civilizations, languages,

All identities that have existed or may exist on this globe, or any globe,

All lives and deaths, all of the past, present, future,

This vast similitude spans them, and always has spann'd,

And this shall forever span them and compactly hold and enclose them. ${ }^{12}$

The gentleness of these great poems can be contrasted with a more ecstatic Whitman in "Song of Myself":

Solitary at midnight in my back yard, my thoughts gone from me a long while,

Walking the old hills of Judaea with the beautiful gentle God by my side,

Speeding through space, speeding through heaven and the stars,

Speeding amid the seven satellites and the broad ring,

and the diameter of eighty thousand miles,

Speeding with tail'd meteors, throwing fire-balls like the rest,

Carrying the crescent child that carries its own full mother in its belly,

Storming, enjoying, planning, loving, cautioning,

Backing and filling, appearing and disappearing,

I tread day and night such roads. ${ }^{13}$

Although death imagery is absent, the visionary excitement, the expansive, bursting energy and absorption in swift cosmic rhythms in these passages are quite similar to the visual impact of van Gogh's painting. In both, one senses the artist working spontaneously, passionately; both are affirmations. Furthermore, Whitman's poem helps us understand the moon's shape in Starry Night. In the painting, the moon surrounds an orb so bright that it has been interpreted as embracing the sun. ${ }^{14}$ One of Whitman's lines reads "Carrying the crescent child that carries its own full mother in its belly"-the part and the whole are simultaneously visible, the enduring and the temporal are expressed by both the painter and the poet in this inspired image.

Whitman and van Gogh used star imagery to embody their most visionary and spiritual experiences. Human life and death are inextricably linked with the awe- 
some interlocking of cosmic rhythms, offering comfort and reassurance even in the face of the remote and spectacular beauty of the universe.

California State College, Stanislaus

HOPE B. WERNESS

\section{NOTES}

1 See Edwin Haviland Miller, ed., A Century of Whitman Criticism (Bloomington: Indiana University Press, 1969), p. 95; and Sven Loevgren, The Genesis of Modernism, Seurat, Gauguin, Van Gogh E French Symbolism in the 1880s (Bloomington, London: Indiana University Press, 1971), pp. 179-183.

2 Vincent van Gogh, The Complete Letters of Vincent van Gogh (Greenwich, Connecticut: New York Graphic Society, 1959), III, \#W8, p. 445. Hereinafter only the letter number will be cited. The author is grateful to Little, Brown and Company for permission to quote portions of van Gogh's letters, all rights reserved. Van Gogh went on to praise the "Prayer of Columbus" as being particularly beautiful. It is difficult to say what else he may have read, but van Gogh read English fluently and Whitman had a significant impact on French letters by the 1880s. Cf. Frederic Schyberg, Walt Whitman (New York 1951), p. 292, cited by Loevgren, pp. 180, $223 \mathrm{n}$. 38.

3 Van Doren is quoted by David Daiches, "Whitman, Impressionist Prophet," in Leaves of Grass One Hundred Years After, ed. Milton Hindus (Stanford: Stanford University Press, 1966), p. 111.

4 A number of other universal themes and motifs appear in the works of both artists, e.g., the journey of life metaphor, birds as soul symbols, the cycles of human life and nature, and the archetypal mother to mention just a few.

5 For other early references to the night sky see letters 27, 91, 100, 101, and 112.

6 Van Gogh painted eleven images of starry or crescent hung skies. Several of the paintings depict human lovers, thereby contrasting temporal and earthly love with enduring, divine love.

7 The Whitman passage quoted above has been frequently noted by van Gogh scholars; however, Loevgren and Lewis M. Layman are the only scholars to have previously quoted Whitman's poetry as a source of influence. Loevgren mentions only "When Lilacs Last in the Dooryard Bloom'd," The Genesis of Modernism, p. 182. Layman, in a recent essay, cites lines 433-447 of "Song of Myself" as "a primary inspiration for 'Starry Night"'; see "Echoes of Walt Whitman's 'Bare-bosom'd Night' in Vincent van Gogh's 'Starry Night," American Notes $\mathcal{E}$ Queries, 22 (March/April 1984), 105-109. In light of the literary inspiration of Starry Night, it is fitting that the painting has inspired a popular song, Don McLean's "Starry, Starry Night," and three poems: E. D. Blodgett, "Untitled," Sounding (Edmonton: University of Alberta, n.d.); Robert Eagles, "The Starry Night," I, Vincent; Poems from the Pictures of Van Gogh (Princeton, New Jersey: Princeton University Press, 1978), p. 81; and W. D. Snodgrass, "Van Gogh: The Starry Night," Delta (Winter 1969/70), 4-11.

8 Stephen Tanner, "Star-Gazing in Whitman's Specimen Days," Walt Whitman Review, 19 (December 1973) 158-161.

9 Tanner, 158.

10 Walt Whitman, Prose Works 1892, 2 vols., ed. Floyd Stovall (New York: New York University Press, 1963), I:252-253. The passage is cited by Tanner, 161. 
11 Walt Whitman, Leaves of Grass, Comprehensive Reader's Edition, ed. Harold W. Blodgett and Sculley Bradley (New York: W. W. Norton \& Company, 1965), p. 335.

12 Whitman, Leaves of Grass, pp. 260-261.

13 Whitman, Leaves of Grass, pp. 64-65.

14 Meyer Schapiro, Vincent van Gogh (Garden City, New York: Doubleday \& Company, Inc., 1980), p. 100.

\section{WALT WHITMAN'S “THERE WAS A CHILD WENT FORTH”: THE IMAGE OF 'EDGES' IN THE ORIGINS OF LIFE}

Walt Whitman's "There Was a Child Went Forth" is a poem of edges that reveals a child's generative touch with the world. His encounter with different objects sharpens his perception, for he touches the world through contrasts and opposites. The first edge is the third-month, the month of March, half winter and half spring, an edge between death and renewal of life in nature. As he literally intersects the edge, he interacts with nature and is able to gain a holistic vision of the animals as the "brood of the barnyard" ${ }^{1}$ rather than seeing them separately. He can now see the "relations in all objects" 2 after he perceives their idiosyncratic differences. Then he encounters, among other objects, the mire of the pond-side-another edge, a combination of water and soil. This edge enables him to perceive the fish against its background, "the curious liquid." Both of these edges suggest the fertile origin of life. The child's contact with the origin of life nourishes what Sherman Paul calls "the developing seed within the self." 3

He encounters the opposing elements in nature, and they become the edging/ sharpening of his perception. After connecting with the world through the edge of the "mire," he is now able to find some sort of unity in different objects:

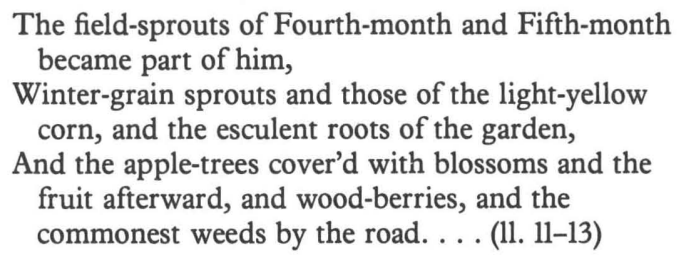

The images of roots, sprouts, blossoms and fruits fascinate him, while his perception unfolds like a "bud."" The contrasts between the images reveal the diverse elements in nature. The winter-grain sprouts are contrasted with roots. The light-yellow corn signifying the fullness of growth stands in opposition to the sprouts and roots which demonstrate to the child the nature of growth as a process. The blossoms with their "fruit afterward" are opposed to the "commonest weeds" on the road. Through the process and the causality of growth, he senses unity in nature's diversity: roots nourish sprouts which eventually blossom and bear fruits. 